\title{
The role of the general practitioner in monitoring pregnant women with hypertension
}

\author{
Rolul medicului de familie în monitorizarea gravidelor cu hipertensiune arterială
}

Mihaela Adela IANCU ${ }^{1,2}$, Mihaela Daniela BALTĂ ${ }^{1,2}$, Ana Maria Alexandra STĂNESCU ${ }^{1,2}$, Adriana TICĂRĂU ${ }^{1,2}$, Oana NICOLESCU ${ }^{3}$, Cristina Mihaela OLARIU ${ }^{1,4}$, Camelia Cristina DIACONU ${ }^{1,5}$, Dumitru MATEI ${ }^{1,6}$

1Universitatea de Medicină şi Farmacie „Carol Davila“, Bucureşti, România

${ }^{2}$ Cabinet medical individual, Bucureşti, România

${ }^{3}$ Direcția de Sănătate Publică, Bucureşti, România

${ }^{4}$ Institutul Național de Boli Infecțioase „Prof. Dr. Matei Balş“, Bucureşti, România

${ }^{5}$ Spitalul Clinic de Urgență, Bucureşti, România

${ }^{6}$ Institutul Național pentru Sănătatea Mamei şi Copilului „Alessandrescu-Rusescu“,

Bucureşti, România

\section{ABSTRACT}

High blood pressure (hypertension) can be one of the most important causes of morbidity or mortality, both maternal and fetal. Monitoring the values of blood pressure during pregnancy and the impact on the health of the pregnant woman and the evolution of the pregnancy by the general practitioner is one of the main prophylactic measures. Surveillance of the pregnant woman, even from the first month of pregnancy, and the identification of risk factors for hypertension are the basis of a diagnosis and early therapeutic intervention, in order to prevent complications. The guidelines also address the intervention and postpartum counseling of these pregnant women on the risk of developing other cardiovascular complications over time, as well as the risk that the next pregnancy will have pregnancy-induced hypertension. The general practitioner, through these interventions, is an important link in the multidisciplinary monitoring team of pregnant women at risk for pregnancy-induced hypertension.
\end{abstract}

Keywords: pregnant, high blood pressure, general practitioner

\section{REZUMAT}

Hipertensiunea arterială (HTA) reprezintă una dintre cele mai importante cauze de morbiditate sau mortalitate, atât maternă, cât şi fetală. Monitorizarea valorilor tensiunii arteriale în timpul sarcinii și a impactului asupra stării de sănătate a gravidei și a evoluției sarcinii de către medicul de familie reprezintă una dintre principalele măsuri profilactice. Supravegherea gravidei, chiar de la luarea în evidență din prima lună de sarcină, şi identifi- 
carea factorilor de risc pentru HTA stau la baza unui diagnostic și a intervenției terapeutice precoce, $\hat{\imath}$ vederea prevenirii complicațiillor. Ghidurile abordează și intervenția și consilierea postpartum a acestor gravide privind riscul în timp de a dezvolta și alte complicații cardiovasculare, precum și riscul pentru următoarea sarcină de a avea HTA indusă de sarcină. Medicul de familie, prin aceste intervenții, reprezintă o verigă importantă în echipa multidisciplinară de monitorizare a femeii gravide cu risc pentru HTA indusă de sarcină.

Cuvinte cheie: gravidă, hipertensiune arterială, medic de familie

\section{INTRODUCERE}

Hipertensiunea arterială (HTA) reprezintă una dintre cele mai importante cauze de morbiditate sau mortalitate, atât maternă, cât și fetală [1]. Hipertensiunea arterială asociată sarcinii complică peste 2-8\% din totalul sarcinilor la nivel global și reprezintă aproximativ un sfert din totalul internărilor pe perioda sarcinii [2]. În America Latină și Caraibe, hipertensiunea arterială asociată sarcinii este responsabilă de aproape $26 \%$ dintre decesele materne, în timp ce în Africa și Asia determină 9\% dintre decese [2].

Hipertensiunea arterială indusă de sarcină înregistrează o prevalență în creștere în ultima perioadă, fiind estimată între 6 și 17\% la femeile nulipare și între 2 și 4\% la multipare [1]. Prevenția și monitorizarea gravidelor cu HTA indusă de sarcină sau asociată sarcinii reprezintă aspecte importante ale supravegherii active lunare a femeiilor gravide de către medicul de familie, din cauza riscului crescut de complicații atât materne, cât și fetale pe care le generează HTA indusă de sarcină, prin evoluția imprevizibilă, prin complicațiile înregistrate, dar și prin reacțiile secundare ale tratamentului farmacologic recomandat. HTA în timpul sarcinii este răspunzătoare pentru $20 \%$ din mortalitatea mamei și 25\% din mortalitatea fetală [1].

Monitorizarea valorilor tensiunii arteriale în timpul sarcinii și a impactului asupra stării de sănătate a gravidei și a evoluției sarcinii de către medicul de familie reprezintă una dintre principalele măsuri profilactice menționate în ultimile ghiduri ale Federației Internaționale de Obstetrică-Ginecologie - 2018 și Societății Europene de Cardiologie - Guidelines for the management of cardiovascular diseases during pregnancy 2018. Acest lucru este motivat și de existența unui număr redus de opțiuni farmacologice existente pentru controlul tensiunii arteriale în sarcină, dar mai ales și din cauza reacțiilor secundare ale tratamentului asupra fătului, cu consecințe ireversibile asupra dezvoltării sale ulterioare [3].

Efectele valorilor crescute ale tensiunii arteriale în timpul sarcinii asupra fătului sunt reprezentate de întârzierea creșterii fetale intrauterine (întâlnite în aproximativ un sfert dintre cazuri), prematuritate (înregistrată în $27 \%$ dintre cazuri) și deces intrauterin (complicație ce apare în aproximativ 4\% dintre cazuri). Complicațiile înregistrate la femeia gravidă sunt reprezentate de abruptio placenta, accident vascular cere- bral, insuficiență multiplă de organ și coagulare intravasculară diseminată (vezi tabel 1).

TABEL 1. Complicații ale hipertensiunii arteriale la gravide

\begin{tabular}{|l|l|}
\hline Complicații fetale & Complicații materne \\
\hline $\begin{array}{l}\text { întârzierea creşterii fetale } \\
\text { intrauterine }\end{array}$ & abruptio placenta \\
\hline prematuritate & accident vascular cerebral \\
\hline deces intrauterin & $\begin{array}{l}\text { insuficiență multiplă de organ } \\
\text { diseminată }\end{array}$ \\
\hline
\end{tabular}

\section{DEFINIT⿱II}

Hipertensiunea arterială preexistentă sarcinii (HTAPS) sau cronică reprezintă hipertensiunea arterială diagnosticată înainte de săptămâna 20 de sarcină sau cunoscută anterior sarcinii, cu sau fără tratament. Valorile crescute ale tensiunii arteriale persistă și la 42 de zile postpartum [4]. HTPS poate fi esențială $(90 \%$ dintre cazuri) sau secundară (10\% dintre cazuri - renoparenchimatoasă, renovasculară, de cauză endocrină - hiperaldosteronismul primar, sindromul Cushing, feocromocitom, sau asociată sindromului de apnee în somn, medicamentoasă etc.) și va trebui tratată și monitorizată și după naștere.

Hipertensiunea arterială gestațională (HTAG) este reprezentată de hipertensiune arterial diagnosticată de novo după săptămâna 20 de sarcină, fără afectare de organ țintă, fără proteinuria prezentă. În momentul apariției proteinuriei $(0,3 \mathrm{~g} / 24 \mathrm{~h})$, evoluția gravidei se complică cu preeclampsie. Evoluția poate fi nefavorabilă, prin apariția convulsiilor, instalarea eclampsiei [4]. Aceste forme de hipertensiune arterială gestațională se remit după 42 de zile postpartum.

Uneori, avem hipertensiunea preexistentă sarcinii, dar cu suprapunerea preeclampsiei sau eclampsiei, iar valorile crescute ale tensiunii arteriale persistă și la 42 de zile postpartum [4].

Vorbim despre hipertensiunea arterială tranzitorie atunci când înregistrăm valori crescute ale tensiunii arteriale la o singură determinare. Pentru a diagnostica HTA de sarcină, este nevoie de minimum 2 determinări diferite ale TA, efectuate la un interval de cel puțin 4 ore, măsurători efectuate în poziție șezândă sau decubit lateral stâng, cu valori ale tensiunii arteriale sis- 
tolice $\geq 140 \mathrm{mmHg}$ sau ale tensiunii arteriale diastolice $\geq 90 \mathrm{mmHg}$ [5]. Dacă la o singură determinare a tensiunii arteriale, în poziție șezândă, după minimum 15 minute de repaus, se înregistrează valori ale tensiunii arteriale sistolice $\geq 160 \mathrm{mmHg}$ sau ale tensiunii arteriale diastolice $\geq 110 \mathrm{mmHg}$, putem pune diagnosticul de HTA de sarcină [3].

Sindromul HELLP reprezintă forma severă de preeclampsie, care asociază H - hemoliză, EL - creșterea enzimelor hepatice, LP - trombocitopenie. Apariția sindromului HELLP este rezultatul activării endoteliale. Sindromul HELLP apare în 0,1\%-0,6\% dintre sarcini și în 4-12\% dintre sarciniile complicate cu preeclampsie. Numai nașterea poate opri cascada declanșată de sindrom HELLP [6].

Etiologia preeclampsiei nu este pe deplin cunoscută. De-a lungul timpului, au fost propuse și studiate mai multe ipoteze. Mecanismele etiologice ale preeclampsiei sunt puțin cunoscute, se consideră a fi un dezechilibru în procesul de angiogeneză [7]. Sunt implicați mai multi factori precum implantarea anormală în a doua etapă a placentei, cu creșterea rezistenței vasculare la nivelul arterelor uterine spiralate, ischemia placentară, stresul oxidativ, disfuncția trofoblastului, factori imunologici, genetici [8]. Studii recente consideră etiologia preeclampsiei ca fiind determinată de relația dintre factorii proangiogenici - reprezentați de factorul de creștere endotelial vascular (VEGF) și factorul de creștere placentar (PIGF) și factorii antiangiogenici - reprezentați de tirozinkinaza solubilă 1 fms-like (sFlt1) și endoglina solubilă (sEng) [9].

\section{MONITORIZAREA GRAVIDEI CU HIPERTENSIUNE ARTERIALĂ}

Ghidurile abordează monitorizarea, intervenția și consilierea acestor gravide privind riscul în timp de a dezvolta și alte complicații cardiovasculare, precum și riscul pentru următoarea sarcină de a avea HTA indusă de sarcină [3]. Noutățile aduse de ghidul Societății Europene de Cardiologie (Guidelines for the management of cardiovascular diseases during pregnancy) 2018 sunt reprezentate de recomandarea ca, în absența proteinuriei, apariția trombocitopeniei poate fi un element în stabilirea diagnosticului de preeclampsie. De asemenea, tot în absența proteinuriei, se poate considera preeclampsie dacă avem: creșteri peste de două ori valorile normale ale transaminazelor hepatice, creșterea creatininei serice peste $1,1 \mathrm{mg} \%$ sau dublare a concentrației serice a creatininei în absența altor afecțiuni renale, precum și apariția edemului pulmonar sau a tulburării cerebrale și/sau vizuale, cu debut brusc $[3,10]$ (vezi tabel 2).

Un aspect important în ultimul ghid al Societății Europene de Cardiologie se referă la monitorizarea auto-
TABEL 2. Criterii de severitate pentru evolutia hipertensiunii arteriale la gravidă $[3,10]$

\begin{tabular}{|l|l|l|}
\hline & Criteriu & Observații \\
\hline 1 & Tensiune arterială & $\begin{array}{l}\text { TAs } \geq 160 \mathrm{mmHg} \text { şi/sau TAd } \geq 110 \\
\mathrm{mmHg}\end{array}$ \\
\hline 2 & Afectarea SNC & $\begin{array}{l}\text { Fotofobie, scotoame } \\
\text { Cefalee severă }\end{array}$ \\
\hline 3 & Afectare hepatică & $\begin{array}{l}\text { Durere epigastrică/hipocondrul } \\
\text { drept persistentă, neresponsivă } \\
\text { la tratament şi fără altă cauză } \\
\text { aparentă } \\
\text { Sau/şi o concentrație serică a } \\
\text { transaminazelor } \geq 2\end{array}$ \\
\hline 4 & Trombocitopenie & $<100.000$ /mm ${ }^{3}$ \\
\hline 5 & Afectare renală & $\begin{array}{l}\text { Insuficiență renală progresivă } \\
\text { (creatinină serică > 1,1 mg/dl sau } \\
\text { dublare a concentrației serice a } \\
\text { creatininei în absența altor afecțiuni } \\
\text { renale) }\end{array}$ \\
\hline
\end{tabular}

mată ambulatorie a TA (MAATA) - monitorizare considerată superioară măsurătorilor de rutină. Măsurarea tensiunii arteriale convenționale în practica clinică în cabinet este cea mai utilizată procedură pentru diagnosticul, monitorizarea și tratamentul hipertensiunii arteriale, dar valorile măsurate depind de tehnică, condiții de măsurare și nu reflectă variabilitatea TA [11]. Se consideră că MAATA evită tratamentul inutil al hipertensiunii de halat alb, al cazurilor de hipertensiune arterială tranzitorie înregistrate la femeile gravide. Ghidul recomandă două indicații pentru MAATA reprezentate de femeile gravide cu risc crescut de hipertensiune arterială și femeile gravide cu diagnostic de nefropatie diabetică sau hipertensivă [3].

În cadrul consultației prenatale, medicul de familie identifică factorii de risc pentru hipertensiunea arterială și realizează prima etapă de consiliere preconceptuală a femeii care își dorește o sarcină. Supravegherea active a gravidei, chiar de la luarea în evidență din prima lună de sarcină, identificarea factorilor de risc pentru HTA, conștientizarea gravidei asupra prezenței factorilor de risc stau la baza unui diagnostic și a intervenției terapeutice precoce, în vederea prevenirii complicațiilor. Factorii de risc implicați în apariția HTA la gravide identificabili de către medicul de familie sunt reprezentați de: vârsta peste 35 de ani la prima sarcină, sarcina multiplă, istoric familial de boli cardiovasculare și de diabet zaharat tip 2, prezența HTA indusă de sarcină în antecedentele personale patologice, obezitatea pregestațională, câștigul ponderal gestațional crescut, valori crescute ale glicemiei, boli de colagen, sindromul antifosfolipidic sau trombofilia (vezi tabel 3). Riscul de a dezvolta preeclampsie este prezent la una din cinci până la una din două gravide diagnosticate inițial cu hipertensiune arterială. 
TABEL 3. Factori de risc pentru apariția preeclampsiei/ eclampsiei

\begin{tabular}{|l|l|}
\hline Factori generali & $\begin{array}{l}\text { primipară } \\
\text { vârsta peste 35 de ani la prima sarcină } \\
\text { interval între sarcini peste 10 ani } \\
\text { fact socioeconomici/culturali }\end{array}$ \\
\hline Factori obstetricali & $\begin{array}{l}\text { sarcina multiplă } \\
\text { sarcină obținută prin FIV } \\
\text { mola hidatiformă } \\
\text { AHC de preeclampsie/eclampsie/HTAG } \\
\text { APP de preeclampsie/eclampsie/HTAG la } \\
\text { sarcini anterioare }\end{array}$ \\
\hline APP & Trombofilie \\
& Lupus eritematos sistemic \\
& HTA \\
& Boală cronică de rinichi \\
& Diabet zaharat tip 2 \\
& Diabet gestațional \\
& Obezitate \\
\hline
\end{tabular}

\section{MĂSURI DE PREVENTTIE PRIMARĂ ŞI SECUNDARĂ}

Pentru a preveni apariția preeclampsiei/eclampsiei, medicul de familie discută cu gravida la risc în cadrul consilierii preconceptuale, după identificarea gravidelor ce au în istoricul medical afecțiunile prezente în tabelul 3. La gravidele cu factori de risc pentru dezvoltarea HTA și a preeclampsiei/eclampsiei, ghidurile recomandă și administrarea în doză scăzută de aspirină 75 mg/zi $[3,10]$.

Deși au fost studiate efectele carenței vitaminice (C, E, D), studiile realizate și publicate nu recomandă administrarea în prevenția primară la gravide cu risc de HTA, de preeclampsie/eclampsie a vitaminei C, E, D sau a suplimentelor de calciu. De asemenea, restricția calorică/proteică la femeile gravide obeze nu scade riscul de preeclampsie, precum nici aportul de sare restricționat sau limitarea activității fizice nu aduc beneficii în vederea scăderii riscului de HTA, preeclampsie/ eclampsie la femeile gravide cu factori de risc prezenți $[1,3,10]$.

Monitorizarea antenatală cuprinde anamneza completă, urmată de examen clinic general, măsurarea greutății, înălțimii, calculul indicelui de masă corporală, înregistrarea creșterii ponderale în timpul sarcinii de la vizita anterioară. Un aspect important este reprezentat de măsurarea TA în decubit lateral stâng sau în poziție șezândă, după minimum 15 minute de repaus. Dintre investigațiile paraclinice de rutină, se recomandă efectuarea periodică a hemoleucogramei complete, glicemiei, testarea funcției hepatice (transaminaze hepatice), testarea periodică a funcției renale (uree, creatinină, sumar de urină, determinarea proteinuriei). De asemenea, se recomandă efectuarea periodică a ecografiei fetale, lunar în cazurile cu factori de risc prezenți, în vederea aprecierii creșterii fetale și a lichidului amniotic și pentru monitorizarea fluxului sanguin în arterele uterine. Un management optim al gravidelor cu valori crescute ale TA are ca etapă inițială și esențială dignosticul diferențial între formele de HTA gestațională și HTA preexistentă sarcinii [12]. În cazul în care se înregistrează modificări ale parametrilor enunțați, se programează gravida în vederea realizării unor examinări suplimentare. În săptămâna 28-32 de sarcină, se recomandă efectuarea de către medicul de familie a testului postural (roll over test). Se consideră pozitiv atunci când se înregistrează creșterea valorilor TA cu peste $20 \mathrm{mmHg}$ la trecerea gravidei în decubit dorsal din poziția de decubit lateral stâng [10].

\section{MONITORIZAREA POSTNATALĂ}

Ghidurile abordează și intervenția și consilierea postpartum a acestor gravide privind riscul în timp de a dezvolta ulterior și alte complicații cardiovasculare, precum și riscul pentru următoarea sarcină de a avea HTA indusă de sarcină.

Se recomandă măsurarea zilnică a tensiunii arteriale în primele 2 zile, cu reducere progresivă a terapiei. Din cauza riscului de favorizare a depresiei și a psihozei postpartum alfa-metildopa - antihipertensivul de elecție folosit pe durata sarcinii -, se va opri în maximum 2 zile, cu schimbarea medicației. Dintre investigațiile paraclinice de rutină, se recomandă efectuarea hemoleucogramei, aprecierea funcției renale și hepatice la 48-72 h postpartum. Se recomandă externarea lăuzei la valori ale $\mathrm{TA} \leq 149 / 99 \mathrm{mmHg}$, cu recomandarea de monitorizare către medicul de familie, indicându-se frecvența monitorizării TA, pragurile de reducere sau oprire a medicației $[2,6]$.

Dacă la 8 săptămâni persistă HTA, cazurile vor fi îndrumate la medicul specialist pentru reclasificare și investigații suplimentare [3].

Monitorizarea postpartum ulterioară urmărește monitorizarea valorilor TA cu ajustarea terapiei, precum și reclasificarea formei de HTA. De asemenea, un aspect important este reprezentat de realizarea consilierii în vederea planificării unei noi sarcini $[3,13]$.

HTAG are prognostic benign și necesită consiliere preconcepție doar dacă există și alți factori de risc adăugați. Se consideră că riscul după preeclampsie la o sarcină ulterioară este de $53 \%$ pentru HTAG, $16 \%$ pentru a dezvolta preeclampsie și de $25 \%$ pentru apariția preeclampsiei sau a eclampsiei după sindrom HELLP, eclampsie, naștere prematură [13].

Femeile cu istoric de preeclampsie au un risc crescut de boli cardiovasculare și metabolice pe termen lung, au un risc de 13 ori mai mare de a avea boală cardiacă ischemică, de 8 ori mai mare de a dezvolta insuficiență cardiacă. De asemenea, crește și riscul de evenimente tromboembolice în următorii 5-15 ani la femeile care au avut preclampsie $[3,13]$. Unele studii arată o creștere semnificativă a riscului de boală croni- 
că de rinichi de 10 ori mai mare la femeile care au prezentat valori arteriale crescute în timpul sarcinii față de cele cu valori normale ale tensiunii arteriale [14]. De asemenea, probabilitatea de apariție a diabetului zaharat de tip 2 pe termen lung se dublează la femeile cu hipertensiune arterială indusă de sarcină [14]. Riscul crescut de apariție a bolilor cardiovasculare și metabolice pe termen lung impune evaluarea prenatală, dar și monitorizarea postpartum în vederea atât a controlului valorilor tensionale, cât și în vederea unui diagnostic precoce de afectare de organ țintă [15].

Cu risc maxim de a dezvolta afecțiuni cardiovasculare pe termen lung sunt considerate femeile cu preeclampsie cu debut precoce (naștere înainte de săptămâna 32 de sarcină) sau cu complicații fetale [3].

\section{CONCLUZII}

Medicul de familie, prin aceste intervenții, reprezintă o verigă importantă în echipa multidisciplinară de monitorizare a femeii gravide cu risc pentru HTA indusă de sarcină.

Supravegherea corectă a gravidei pe parcursul evoluției sarcinii constituie unul dintre principalele mijloace de identificare a factorilor de risc pentru hipertensiune arterială, diagnostic precoce și tratament corespunzător, cu reducerea semnificativă a complicațiilor materne și fetale ale hipertensiunii arteriale în sarcină.

Monitorizarea de către medicul de familie pe termen lung - după remiterea HTAG - este obligatorie, pentru a reduce riscul de recidivă a HTAG la o nouă sarcină, precum și riscul cardiovascular semnificativ al acestor femei pe termen lung.

\section{Mențiune}

Toți autorii au contribuit în mod egal la realizarea acestui articol.

Conflict of interest: none declared Financial support: none declared

\section{BIBLIOGRAFIE}

1. Rachel James P, Nelson Piercy C. Management of hypertension before, during, and after pregnancy. Heart 2004;90:1499-1504.

2. Gestational Hypertension and Preeclampsia: ACOG Practice Bulletin, Number 222. Obstet Gynecol. 2020;135(6):e237.

3. Regitz-Zagrosek V et al. 2018 ESC Guidelines for the management of cardiovascular diseases during pregnancy: The Task Force for the Management of Cardiovascular Diseases during Pregnancy of the European Society of Cardiology (ESC). European Heart Journal 2018;39(34):3165-3241.

4. Tranquilli AL, Dekker G, Magee L, Roberts J, Sibai BM, Steyn W, Zeeman GG, Brown MA. The classification, diagnosis and management of the hypertensive disorders of pregnancy: A revised statement from the ISSHP. Pregnancy Hypertens. 2014;4(2):97.

5. Nanu D, Marinescu B, Matei D, Isopescu F. Esenţialul în obstetrică. Bucureşti: Editura Medicală Amaltea, 2008.

6. Sibai BM. Diagnosis, controversies, and management of the syndrome of hemolysis, elevated liver enzymes, and low platelet count. Obstet Gynecol. 2004;103(5 Pt 1):981.

7. Sufriyana H, Wu YW, Su EC. Prediction of Preeclampsia and Intrauterine Growth Restriction: Development of Machine Learning Models on a Prospective Cohort. JMIR Med Inform. 2020;8(5):e15411.

8. Maynard SE, Min JY, Merchan J, Lim KH, Li J, Mondal S, Libermann TA, Morgan JP, Sellke FW, Stillman IE, Epstein FH, Sukhatme VP, Karumanchi S. Excess 14 placental soluble fms-like tyrosine kinase 1 (sFlt1) may contribute to endothelial dysfunction, hypertension, and proteinuria in preeclampsia. $J$ Clin Invest 2003;111:649-658.

9. Li L, Zheng Y, Zhu Y, Li J. Serum biomarkers combined with uterine artery Doppler in prediction of preeclampsia. Exp Ther Med. 2016;12(4):2515-2520.

10. American College of Obstetricians and Gynecologists' Committee on Practice Bulletins - Obstetrics in collaboration with Jimmy Espinoza, MD, MSc; Alex Vidaeff, MD, MPH; Christian M. Pettker, MD; and Hyagriv Simhan, MD. ACOG Practice Bulletin No. 202: Gestational Hypertension and Preeclampsia. Obstet Gynecol 2019.
11. Gijon-Conde T, Gorostidi M, Banegas JR et al. Position Statement on Ambulatory Blood Pressure monitoring (ABPM) by the Spanish Society of Hypertension 2019. Hipertens Riesgo Vasc. 2019;36(4):199212.

12. Sava RI, March KL, Pepine CJ. Hypertension in Pregnancy: Taking Cues From Pathophysiology for Clinical Practice. Clin Cardiol. 2018;41(2):220-227.

13. https://www.nice.org.uk/guidance/ng133 Hypertension in pregnancy. The management of hypertensive disorders during pregnancy. NICE clinical guideline, 2019.

14. Alvarez-Alvarez B, Martell-Claros N, Abad-Cardiel M et al. Hypertensive Disorders During Pregnancy: Cardiovascular long-term Outcomes. Hipertens Riesgo Vasc. 2017;34(2):85-92.

15. Reddy S, Jim B. Hypertension and Pregnancy: Management and Future Risks. Adv Chronic Kidney Dis. 2019;26(2):137145. 